\title{
PRECISION OF A CRYSTAL STRUCTURE DERIVED FROM A SYNCHROTRON X-RAY POWDER PATTERN. THE STRUCTURE OF BARIUM OXALATE HYDRATE, $\mathrm{BaC}_{2} \mathrm{O}_{4} \cdot 2 \mathrm{H}_{2} \mathrm{O}$
}

\author{
A. NØRLUND CHRISTENSEN, $\uparrow$ R. G. HAZELL, $\dagger$ A. M. T. BELL $\neq \|$ and A. ALTOMARE $\S$ \\ †Department of Inorganic Chemistry, Aarhus University, DK-8000 Aarhus C, Denmark \\ \$Department of Chemistry, University of Keele, Keele, Staffordshire ST5 5BG, U.K. \\ §Instituto di Riccrca per lo Sviluppo di Metodologie Cristallografiche, CNR, c/o Dipartimento Geomineralogico, Campus \\ Universitario, I-70124 Bari, Italy
}

(Received 21 October 1994; accepted 26 October 1994)

\begin{abstract}
The crystal structure of barium oxalate hydrate, $\mathrm{BaC}_{2} \mathrm{O}_{4} \cdot 2 \mathrm{H}_{2} \mathrm{O}$, was reinvestigated using a synchrotron $X$-ray powder pattern and a single crystal $X$-ray data set. The compound is monoclinic, $a=7.538(1), b=11.062(1), c=7.105(1) \AA$ of the structure arrived at with the synchrotron $X$-ray powder pattern is not as high as that obtained with the single crystal $X$-ray data. The barium atoms are bonded to the oxalate ions and to the water molecules with nine barium oxygen bonds in the range $2.71(1)-2.97(1) \AA$. The structure has hydrogen bonds in the range $2.72(2)-2.91(2) \AA$, and the oxalate ion has only a minor deviation from planarity.
\end{abstract}

Keywords: D. crystal structure.

\section{INTRODUCTION}

The crystal structure of $\mathrm{BaC}_{2} \mathrm{O}_{4} \cdot 2 \mathrm{H}_{2} \mathrm{O}$ has earlier been studied by a single crystal $\mathrm{X}$-ray film technique using MoK $_{\alpha}$ radiation [1]. Visually estimated intensities, a total of 957 , were used in the structure analysis which resulted in rather large standard deviations of the atomic coordinates of the model of the structure [1]. In an ongoing investigation of the crystal chemistry of oxalates [2-4], powders as well as single crystals of $\mathrm{BaC}_{2} \mathrm{O}_{4} \cdot 2 \mathrm{H}_{2} \mathrm{O}$ were synthesized. A synchrotron $\mathrm{X}$-ray powder pattern of the compound was used to test if the structure could be solved by direct methods. The structure was then refined by the Rietveld method [5], and a single crystal $\mathrm{X}$-ray analysis was done to improve the precision of the structure and to study the hydrogen bonds in $\mathrm{BaC}_{2} \mathrm{O}_{4} \cdot 2 \mathrm{H}_{2} \mathrm{O}$.

\section{EXPERIMENTAL}

\subsection{Sample preparation}

The barium oxalates were made from $\mathrm{CO}_{2}$ free solutions of $\mathrm{BaCl}_{2} \cdot 2 \mathrm{H}_{2} \mathrm{O}$ (Merck p.a.), $\left(\mathrm{NH}_{4}\right)_{2} \mathrm{C}_{2} \mathrm{O}_{4} \cdot \mathrm{H}_{2} \mathrm{O}$ (Merck p.a.), and $\mathrm{H}_{2} \mathrm{C}_{2} \mathrm{O}_{4} \cdot \mathrm{H}_{2} \mathrm{O}$ (Ferak p.a.). The purity of the barium oxalates was investigated with Guinier photographs which were

|| Present address: DRAL Daresbury Laboratory, Daresbury, Warrington, Cheshire WA4 4AD, U.K. taken with a Nonius Guinier camera using $\mathrm{CuK}_{\alpha}$ radiation $(\lambda=1.540598 \AA)$ and silicon as an internal standard $\left(a_{\mathrm{Si}}=5.43050 \AA\right)$. The positions and intensities of the Bragg reflections on the Guinier films were measured on a photometer and were compared with the values on the respective JCPDS data cards.

The powder sample of $\mathrm{BaC}_{2} \mathrm{O}_{4} \cdot 2 \mathrm{H}_{2} \mathrm{O}$ was obtained in attempts to make samples of $\mathrm{BaC}_{2} \mathrm{O}_{4} \cdot 3.5 \mathrm{H}_{2} \mathrm{O}$ : solutions of $12.2 \mathrm{~g} \mathrm{BaCl}_{2} \cdot 2 \mathrm{H}_{2} \mathrm{O}$ in $500 \mathrm{ml}$ water and of $4.5 \mathrm{~g} \mathrm{H}_{2} \mathrm{C}_{2} \mathrm{O}_{4} \cdot \mathrm{H}_{2} \mathrm{O}$ in $500 \mathrm{ml}$ water were cooled to $5^{\circ} \mathrm{C}$ in an ice bath. A solution of oxalic acid was added dropwise to the barium chloride solution which was stirred with a magnetic stirrer and kept at $5^{\circ} \mathrm{C}$. The white crystalline precipitate of $\mathrm{BaC}_{2} \mathrm{O}_{4} \cdot 3.5 \mathrm{H}_{2} \mathrm{O}$ was filtered on a Büchner funnel, washed with water and ethanol and stored in a polyethylene flask. $\mathrm{BaC}_{2} \mathrm{O}_{4} \cdot 3.5 \mathrm{H}_{2} \mathrm{O}$ is unstable at room temperature. It can be kept in a refrigerator or over dry ice in a dewar for some days, but at room temperature it converts to $\mathrm{BaC}_{2} \mathrm{O}_{4} \cdot 2 \mathrm{H}_{2} \mathrm{O}$ in a few days and in weeks to $\mathrm{BaC}_{2} \mathrm{O}_{4} \cdot \mathrm{H}_{2} \mathrm{O}$. The single crystal sample of $\mathrm{BaC}_{2} \mathrm{O}_{4} \cdot 2 \mathrm{H}_{2} \mathrm{O}$ was obtained as reported previously [3].

\subsection{X-ray diffraction}

A synchrotron X-ray powder diffraction pattern of $\mathrm{BaC}_{2} \mathrm{O}_{4} \cdot 2 \mathrm{H}_{2} \mathrm{O}$ was measured at $25^{\circ} \mathrm{C}$, using the high resolution powder diffractometer on Station 2.3 of the Daresbury Laboratory Synchrotron Radiation 
Table 1. Experimental data and unit cell parameters for $\mathrm{BaC}_{2} \mathrm{O}_{4} \cdot 2 \mathrm{H}_{2} \mathrm{O}$

\begin{tabular}{lc}
\hline Powder sample, Daresbury, Station & 2.3. \\
$2 \theta_{\min }\left({ }^{\circ}\right)$ & 10.00 \\
$2 \theta_{\max }\left({ }^{\circ}\right)$ & 124.99 \\
$\Delta 2 \theta\left({ }^{\circ}\right)$ & 0.01 \\
$\lambda(\AA)$ & 1.4039 \\
Max $\sin \theta / \lambda\left(\AA^{-1}\right)$ & 0.632 \\
Flat plate & Yes \\
Frequency of rotation (rpm) & 50 \\
$a(\AA)$ & $7.525(1)$ \\
$b(\AA)$ & $11.048(1)$ \\
$c(\AA)$ & $7.092(1)$ \\
$\beta\left({ }^{\circ}\right)$ & $105.40(1)$
\end{tabular}

Single crystal, Huber diffractometer.

$a(\mathrm{~A})$

$b(\AA)$

$c(\AA)$

$\beta\left(^{\circ}\right)$

Space group

$Z$

Size of crystal (mm)

Density (calcd.) $\left(\mathrm{g} \mathrm{cm}^{-3}\right)$

Linear absorption

Coefficient, $\mu \mathrm{Mo}\left(\mathrm{cm}^{-1}\right)$

No. of measured reflections

No. of independent reflections

Scan method

Scan range in $\theta$

$7.538(1)$
$11.062(1)$
$7.105(1)$
$105.42(1)$
$\mathrm{P} 2{ }_{1} / \mathrm{c}$
4
$0.05 \times 0.10 \times 0.12$
3.12
73
2354
1243
$\omega-2 \theta$
$1+0.346 \tan \theta$

Source, U.K. [6, 7]. A pattern was also measured for a NBS $(640$ a) silicon standard sample to calibrate the synchrotron $\mathrm{X}$-ray wavelength. A sample of $\mathrm{BaC}_{2} \mathrm{O}_{4} \cdot 3.5 \mathrm{H}_{2} \mathrm{O}$ tested as a pure sample from its Guinier photograph was kept at room temperature for 4 days and was, when the measurement had been made at the synchrotron source, almost completely converted to $\mathrm{BaC}_{2} \mathrm{O}_{4} \cdot 2 \mathrm{H}_{2} \mathrm{O}$. The experimental conditions for the measurement of the pattern are listed in Table 1.

The single crystal X-ray diffraction data were measured on a Huber four-circle diffractometer using $\operatorname{MoK}_{\alpha}$ radiation $(\lambda=0.7107 \AA)$. The unit cell parameters were calculated in a least-squares refinement using diffraction data from 117 reflections. Data for the single crystal investigation are listed in Table 1.

\section{RESULTS}

Structure factors were extracted from the synchrotron $\mathrm{X}$-ray powder pattern using the program ALLHKL [8]. The 665 structure factors thus obtained were used in the direct method program SIRPOW92 [9], which located seven of the non-hydrogen atoms in the structure. The program gave a solution with 13 atomic positions, but six of these were in error, and the positions of the two atoms $\mathrm{C} 2$ and $\mathrm{O} 2$ were not located, see Table 2.

A model of the structure was refined using the solution found from SIRPOW92, and the positions of the atoms $\mathrm{C} 2$ and $\mathrm{O} 2$ reported previously [1]. The
Table 2. Atomic coordinates and equivalent atomic displacement factors for $\mathrm{BaC}_{2} \mathrm{O}_{4} \cdot 2 \mathrm{H}_{2} \mathrm{O}$. For each atom are listed four sets of coordinates: (i) Values reported in Ref. [1] with digits corresponding to one digit in the standard deviation; (ii) solution found with SIRPOW92; (iii) coordinates from profile refinement of the synchrotron X-ray powder pattern; (iv) coordinates from the single crystal $\mathrm{X}$-ray diffraction analysis

\begin{tabular}{|c|c|c|c|c|}
\hline Atom & $x / a$ & $y / b$ & $z / c$ & $U$ eq* 1000 \\
\hline \multirow[t]{4}{*}{$\mathrm{Ba}$} & $0.1910(2)$ & 0.0089 (1) & $0.2887(2)$ & \\
\hline & 0.192 & 0.012 & 0.288 & \\
\hline & $0.1933(2)$ & $0.0073(3)$ & 0.2895 (3) & \\
\hline & $0.1913(1)$ & $0.0086(1)$ & 0.2889 (1) & $15(1)$ \\
\hline \multirow[t]{4}{*}{$\mathrm{Cl}$} & $0.794(4)$ & $0.299(2)$ & 0.569 (4) & \\
\hline & 0.780 & 0.296 & 0.582 & \\
\hline & $0.756(3)$ & $0.352(3)$ & $0.581(5)$ & \\
\hline & $0.793(3)$ & 0.298 (1) & $0.577(3)$ & $15(8)$ \\
\hline \multirow[t]{3}{*}{$\mathrm{C} 2$} & $0.963(2)$ & $0.251(2)$ & $0.511(2)$ & \\
\hline & $0.964(3)$ & $0.235(3)$ & $0.490(6)$ & \\
\hline & $0.964(2)$ & 0.254 (1) & $0.511(2)$ & $12(8)$ \\
\hline \multirow[t]{4}{*}{ Ol } & $0.758(3)$ & $0.411(2)$ & 0.559 (3) & \\
\hline & 0.750 & 0.386 & 0.529 & \\
\hline & $0.760(2)$ & $0.424(2)$ & $0.542(3)$ & \\
\hline & $0.766(2)$ & $0.411(1)$ & $0.567(2)$ & $27(8)$ \\
\hline \multirow[t]{3}{*}{$\mathrm{O} 2$} & 0.692 & $0.218(2)$ & $0.629(3)$ & \\
\hline & $0.678(2)$ & $0.232(2)$ & $0.643(3)$ & \\
\hline & $0.691(2)$ & $0.222(1)$ & $0.629(2)$ & $19(7)$ \\
\hline \multirow[t]{4}{*}{ O3 } & $0.983(2)$ & $0.141(2)$ & $0.501(2)$ & \\
\hline & 1.002 & 0.149 & 0.546 & \\
\hline & $0.982(2)$ & $0.142(2)$ & 0.479 (4) & \\
\hline & $0.986(2)$ & $0.141(1)$ & $0.503(3)$ & $24(7)$ \\
\hline \multirow[t]{4}{*}{ O4 } & $0.064(4)$ & 0.334 (1) & $0.471(3)$ & \\
\hline & 0.059 & 0.325 & 0.477 & \\
\hline & $0.085(2)$ & $0.331(2)$ & 0.441 (3) & \\
\hline & $0.062(2)$ & $0.334(1)$ & $0.467(2)$ & $20(6)$ \\
\hline \multirow[t]{4}{*}{ O5 } & $0.434(4)$ & $0.023(2)$ & $0.695(4)$ & \\
\hline & 0.461 & -0.004 & 0.674 & \\
\hline & $0.418(1)$ & $0.023(2)$ & $0.721(2)$ & \\
\hline & $0.419(2)$ & 0.025 (1) & $0.689(2)$ & $24(6)$ \\
\hline \multirow[t]{4}{*}{ O6 } & $0.355(4)$ & $0.243(2)$ & $0.352(3)$ & \\
\hline & 0.328 & 0.256 & 0.345 & \\
\hline & 0.379 (1) & $0.223(2)$ & $0.325(3)$ & \\
\hline & $0.356(2)$ & $0.245(1)$ & 0.359 (2) & $28(8)$ \\
\hline $\mathrm{H1}$ & 0.403 & 0.103 & 0.740 & \\
\hline $\mathrm{H} 2$ & 0.382 & -0.036 & 0.765 & \\
\hline $\mathrm{H} 3$ & 0.460 & 0.245 & 0.443 & \\
\hline $\mathrm{H} 4$ & 0.267 & 0.273 & 0.393 & \\
\hline
\end{tabular}

$U$ eq $=(1 / 3) \sum_{i} \sum_{j} U_{i j} a_{i}^{*} a_{j}^{*} a_{i} a_{j}$.

profile refinement procedure by Rietveld [5] was applied using the program DBW3.2S [10], and the scattering lengths contained in the program. The results of the refinement are listed in Table 2.

From the single crystal diffraction data 1243 reflections with $I>3 \sigma(I)$ were used in the least squares refinement with the program LINUS [11], and scattering contributions from neutral atoms [12]. Starting parameters were taken from the previously reported model of the structure [1], and the positions of the hydrogen atoms in the water molecules were calculated assuming tetrahedral bond directions for the oxygen atoms of the water molecules. The weighting scheme used was $w=1 / \sigma$, where $\sigma=\left[\sigma_{\text {count }}\left(F^{2}\right)+\right.$ $\left.1.06 F^{2}\right]^{1 / 2}-|F|$ and $\sigma_{\text {count }}\left(F^{2}\right)-$ (number of 
Table 3. Interatomic distances in $\AA$ and angles in degrees. Standard deviations in parentheses

\begin{tabular}{llll}
\hline $\mathrm{C} 1-\mathrm{O} 1$ & $1.26(2)$ & $\mathrm{O} 1-\mathrm{Cl}-\mathrm{O} 2$ & $125(2)$ \\
$\mathrm{Cl} 1-\mathrm{O} 2$ & $1.26(2)$ & $\mathrm{O} 2-\mathrm{Cl}-\mathrm{C} 2$ & $120(1)$ \\
$\mathrm{C} 1-\mathrm{C} 2$ & $1.56(2)$ & $\mathrm{Cl}-\mathrm{C} 2-\mathrm{O} 3$ & $117(1)$ \\
$\mathrm{C} 2-\mathrm{O} 3$ & $1.26(2)$ & $\mathrm{O} 3-\mathrm{C} 2-\mathrm{O} 4$ & $127(2)$ \\
$\mathrm{C} 2-\mathrm{O} 4$ & $1.25(2)$ & $\mathrm{O} 4-\mathrm{C} 2-\mathrm{C} 1$ & $116(1)$ \\
& & $\mathrm{C} 2-\mathrm{Cl}-\mathrm{O} 1$ & $115(2)$ \\
$\mathrm{Ba}-\mathrm{O} 2$ & $2.711(12)$ & & \\
$\mathrm{Ba}-\mathrm{O} 3$ & $2.784(14)$ & & \\
$\mathrm{Ba}-\mathrm{O} 4$ & $2.831(13)$ & & \\
$\mathrm{Ba}-\mathrm{O} 3$ & $2.844(15)$ & & \\
$\mathrm{Ba}-\mathrm{O} 1$ & $2.847(13)$ & & \\
$\mathrm{Ba}-\mathrm{O} 6$ & $2.877(14)$ & & \\
$\mathrm{Ba}-\mathrm{O} 5$ & $2.911(13)$ & & \\
$\mathrm{Ba}-\mathrm{O} 5$ & $2.921(14)$ & & \\
$\mathrm{Ba}-\mathrm{O} 4$ & $2.974(14)$ & & \\
\hline
\end{tabular}

counts) ${ }^{1 / 2}$. Anisotropic atomic displacement parameters were refined for the non-hydrogen atoms, but the positions and isotropic atomic displacement parameters were not refined for the hydrogen atoms. The final $R$ values obtained were $R=7.5 \%, R_{\mathrm{w}}=9.2 \%$, and the final values of the refined parameters are listed in Table 2. Interatomic distances are listed in Table 3, and Fig. 1 is a stereoscopic drawing of the structure.

\section{DISCUSSION}

Using the direct method program SIRPOW92 [9] it was possible to locate seven of the nine non-hydrogen atoms of the structure by using the synchrotron $\mathrm{X}$-ray powder pattern of $\mathrm{BaC}_{2} \mathrm{O}_{4} \cdot 2 \mathrm{H}_{2} \mathrm{O}$. The positions of the remaining two atoms were known from Ref. [1]. The number of parameters refined in the least squares profile refinement was for $\mathrm{BaC}_{2} \mathrm{O}_{4} \cdot 2 \mathrm{H}_{2} \mathrm{O}: 27$ positional parameters, one overall temperature factor, four unit cell parameters, two preferred orientation parameters, three profile parameters, two mixing parameters and a scale factor, and for $\mathrm{BaC}_{2} \mathrm{O}_{4} \cdot 3.5 \mathrm{H}_{2} \mathrm{O}$ : one scale factor. The impurity of $\mathrm{BaC}_{2} \mathrm{O}_{4} \cdot 3.5 \mathrm{H}_{2} \mathrm{O}$ in the sample of $\mathrm{BaC}_{2} \mathrm{O}_{4} \cdot 2 \mathrm{H}_{2} \mathrm{O}$ was estimated to be $0.9 \%$. The precision of the atomic coordinates in the structure of $\mathrm{BaC}_{2} \mathrm{O}_{4} \cdot 2 \mathrm{H}_{2} \mathrm{O}$ derived from the profile refinement of the synchrotron X-ray powder pattern is comparable to the precision obtained in the single crystal investigation using an $\mathrm{X}$-ray film technique [1]. However, the standard deviations arrived at in profile refinements may well be underestimated, and taking that into consideration the precision obtained in the profile refinement may be lower than that reported previously for the positional parameters of the model [1]. The refinement of the single crystal diffractometer data gave, as expected, a set of positional parameters with higher precision than obtained previously [1]. This model of the structure is assumed to be more accurate than that obtained from the film data [1] and certainly has a higher accuracy than the model arrived at from the profile refinement of the synchrotron $\mathrm{X}$-ray data.

The crystal structure of $\mathrm{BaC}_{2} \mathrm{O}_{4} \cdot 2 \mathrm{H}_{2} \mathrm{O}$ has one independent barium atom coordinated with nine oxygen atoms, six oxygen atoms from the oxalate ions, and three oxygen atoms from the water molecules. The interatomic distances in this coordination are listed in Table 3. The oxalate ion is planar with the following distances to the best plane through the six atoms: $\mathrm{C} 10.02 \AA, \mathrm{C} 20.01 \AA, 01-0.05 \AA, 020.03 \AA$, $\mathrm{O} 3-0.05 \AA, \mathrm{O} 40.04 \AA$. The oxalate ion thus has only a minor deviation from planarity.

The hydrogen atom positions of the water molecules were derived from packing considerations. The water molecules take part in the following hydrogen bonds: $\mathrm{O} 5$ is bonded to $\mathrm{O} 1$ and $\mathrm{O} 6$ with hydrogen bonds of 2.80 (2) and 2.91(2) $\AA$, respectively, and 06 is bonded to $\mathrm{O} 4$ and $\mathrm{O} 2$ with hydrogen bonds of $2.72(2)$ and $2.74(2) \AA$, respectively, and to O5 as mentioned above.

Acknowledgements - The Powder Diffraction Service at SERC Daresbury Laboratory, Warrington, U.K., is acknowledged for the use of the synchrotron $\mathrm{X}$-ray powder diffractometer. The Danish Natural Science Research Council and Carlsbergfondet are acknowledged for contributing financially to the four-circle diameter. Mrs M. A. Chevallier, Mrs C. Secher and Mr N. J. Hansen are thanked for valuable assistance.
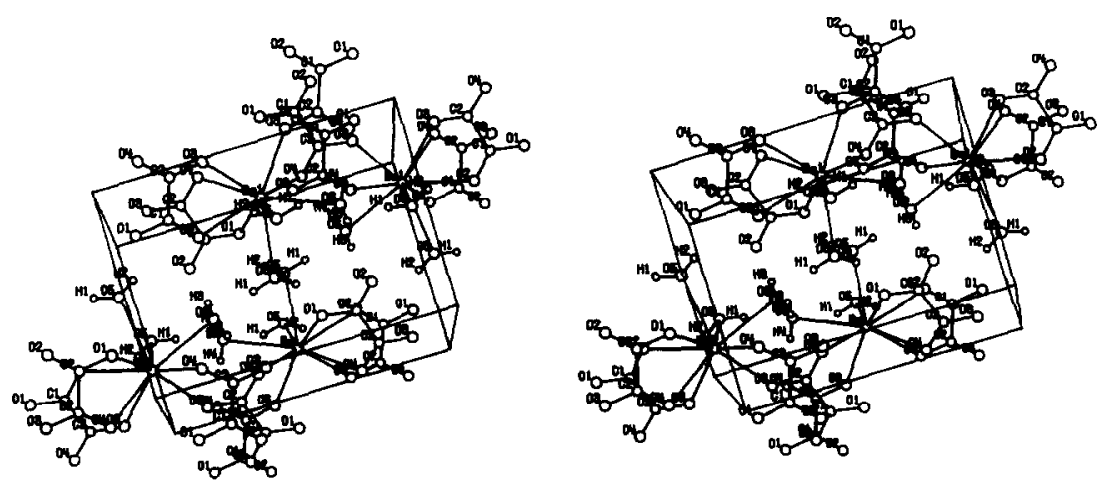

Fig. 1. Stereoscopic view of the structure of $\mathrm{BaC}_{2} \mathrm{O}_{4} \cdot 2 \mathrm{H}_{2} \mathrm{O}$ along [001]. 


\section{REFERENCES}

1. Mutin J.-C., Courtois A., Bertrand G., Protas J. and Watelle-Marion G., C.R. Acad. Sci. (Paris), Ser. C 273, 1512 (1971).

2. Christensen A. N., Cox D. E. and Lehmann M. S., Acta Chem. Scand. 43, 19 (1989).

3. Christensen A. N., Acta Chem. Scand. 46, 240 (1992).

4. Christensen A. N., Norby P. and Hanson J. C., $Z$. Kristallogr. 209, 874 (1994).

5. Rietveld H. M., J. Appl. Crystallogr. 2, 65 (1989).

6. Cernik R. J., Murray P. K., Pattison P. and Fitch A. N., J. Appl. Crystallogr. 23, 292 (1990).

7. Collins S. P., Cernik R. J., Pattison P., Bell A. M. T. and Fitch A. N., Rev. Sci. Instrum. 63(1), 1013 (1992).

8. Pawley G. S., J. Appl. Crystallogr. 14, 357 (1981).
9. Altomare A., Cascarano G., Giacovazzo C., Guagliardi A., Burla M. C., Polidori G. and Camalli M., J. Appl. Crystallogr. 27, 434 (1994).

10. Wiles D. B., Sakthivel A. and Young R. A., Program DBW3.2S for Rietveld Analysis of X-Ray and Neutron Powder Diffraction Patterns. School of Physics, Georgia Institute of Technology, Atlanta, GA (1988).

11. Busing W. R., Martin K. O. and Levy H. A., ORFLS, A Fortran Crystallographic Least Squares Program. Rcport ORNL-TM 305, Oak Ridge National Laboratory, Oak Ridge (1962). LINUS is a 1971 version of ORFLS.

12. Cromer D. T. and Waber J. T., Report LA-3056, Los Alamos Scientific Laboratory of the University of California, Los Alamos, NM (1964). 